\title{
Survival after outplanting of the ectomycorrhizal fungus Laccaria bicolor S238N inoculated on Douglas fir (Pseudotsuga menziesii (Mirb.) Franco) cuttings
}

\author{
Céline Di Battista ${ }^{\mathrm{a}}$, Daniel Bouchard ${ }^{\mathrm{b}}$, Francis Martin $^{\mathrm{b}}$, Benoit Genere $^{\mathrm{c}}$, \\ Jean-Michel Amirault ${ }^{\mathrm{d}}$ and François Le Tacon ${ }^{\mathrm{b}, *}$
}

a Unité Agronomie et Environnement, UC 864 INRA ENSAIA, 2, avenue de la Forêt de Haye, BP 172, 54505 Vandœuvre-les-Nancy Cedex, France

${ }^{b}$ Unité Mixte de Recherches Interactions Arbres-Microorganismes, INRA Centre de Nancy, 54280 Champenoux, France

${ }^{c}$ Direction Départementale de l'Agriculture et de la Forêt, Cité administrative, 2 rue Saint-Sever, 76032 Rouen, France

${ }^{\mathrm{d}}$ CEMAGREF - Domaine des Barres, 45290 Nogent-sur-Vernisson, France

(Received 6 March 2001; accepted 14 September 2001)

\begin{abstract}
Selected strains of ectomycorrhizal fungi can be inoculated in forest nurseries to improve survival and growth of seedlings or cuttings after field transplantation. The survival of the American strain Laccaria bicolor S238N on Douglas fir cuttings was evaluated in nursery and field conditions three years after outplanting using morphological and PCR/RFLP of nuclear rDNA spacers. The comparison of the mycorrhizal status of Douglas fir cuttings at the end of the nursery phase and two years after outplanting shown several behaviours among the ectomycorrhizal fungi naturally occurring in the nursery or artificially introduced. The naturally occurring Rhizopogon type disappeared after outplanting, while the inoculated strain Laccaria bicolor $\mathrm{S} 238 \mathrm{~N}$ and an unknown type (1/2 ITS ribotype) survived and competed with the naturally occurring fungi of the outplanting site. Only one indigenous type (1/3 ITS ribotype) seemed occurring in the outplanting site where Cenococcum geophilum was almost completely absent.
\end{abstract}

Douglas fir / mycorrhizas / nursery / transplantation

Résumé - Survie après transplantation de la souche ectomycorhizienne Laccaria bicolor S238N associée à des boutures de Douglas. Des souches sélectionnées de champignons ectomycorhiziens peuvent être inoculées en pépinières forestières afin d'améliorer la survie et la croissance des plants après transplantation en forêt. La survie de la souche fongique américaine Laccaria bicolor S238N associée à des plants de Douglas issus de boutures a été évaluée en pépinière et trois ans après la transplantation sur un site de reboisement par description morphologique et utilisation d'outils moléculaires (PCR/RFLP de l'ADN ribosomal nucléaire). La comparaison du statut mycorhizien des plants de Douglas à la fin de la phase de pépinière et trois ans après la transplantation a permis de mettre en évidence plusieurs différences de comportement entre les espèces fongiques naturelles ou introduites de la pépinière. Le Rhizopogon naturellement présent en pépinière disparaît après transplantation, alors que la souche inoculée Laccaria bicolor $\mathrm{S} 238 \mathrm{~N}$ et un type inconnu (ribotype 1/2 ITS) survivent et montrent une bonne capacité de compétition avec les espèces fongiques naturelles du site de plantation. Seul un ribotype indigène semble avoir une capacité de compétition importante sur le site de plantation où Cenococcum geophilum est presque complètement absent.

\section{Douglas / mycorrhizes / pépinière / transplantation}

\footnotetext{
* Correspondence and reprints

Tel.: 33-3 833940 41; Fax: 33-3 833940 69; e-mail: le_tacon@nancy.inra.fr
} 


\section{INTRODUCTION}

Ectomycorrhizal symbiosis, a mutualistic plant-fungus association, plays a fundamental role in the biology and ecology of forest trees, affecting growth, water and nutrient absorption, and providing protection from root diseases [27]. Mycorrhizal inoculation of seedlings with selected ectomycorrhizal fungi can be used to improve survival, establishment, and growth of seedlings after outplanting. Evidence of growth stimulation after outplanting in forest conditions of inoculated sedlings has often been reviewed $[19,21,22,28]$. The extent to which these benefits are realised on the planting sites depends on the rate of initial fungal colonisation, dissemination and persistence of the inoculated symbiotic fungus, and biotic and abiotic features specific to each site [13].

Assessing the occurrence and spatial distribution of an inoculated ectomycorrhizal fungus requires the ability to track a strain on the root system. Morphological methods have been used to survey the presence in outplanting sites of fungal strains inoculated in nursery beds several years before. Despite the imprecision of such methods, some results are available in the litterature. McAfee and Fortin [20] observed on Pinus banksiana seedlings that the inoculated fungus, Laccaria bicolor, colonised $55 \%$ of the short roots after two months in the field. Danielson and Visser [7] found that Laccaria proxima and Thelephora terrestris were completely superseded by naturally occurring fungi one year after transplantation. Bledsoe et al. [3] observed on Douglas fir seedlings that Laccaria laccata and Hebeloma crustuliniforme, previously inoculated in nursery, were unable to colonise new-formed roots in field conditions. Villeneuve et al. [29] found that mycorrhizal colonisation by Laccaria species (54\%) on Laccaria inoculated Douglas fir seedlings was significantly greater that on controls $(13 \%)$ two years after transplantation in forest conditions. Nevertheless, all these results based on morphological assessment have to be considered with caution. Owing to the large morphotype variation, it is impossible to ascertain that a given introduced strain is still present on the root system several years after outplanting when morphological methods are used.

Potential usefulness of PCR-based analysis to identify fungal isolates at the intraspecific level has been demonstrated [4-6, 9-11, 14]. Henrion et al. [15, 16], showed that molecular techniques could be used in nursery to monitor introduced ectomycorrhizal fungi, together with indigenous ones. A research program has been developed in France over the last 20 years to improve growth and survival of Douglas fir [Pseudotsuga menziesii (Mirb.) Franco] by inoculation of seedlings with Laccaria bicolor S238N [19]. Douglas fir also can be vegetatively propagated as rooted cuttings from selected mother trees [23]. Cuttings propagation of selected trees can lead to an increased growth after field transplantation. One of the most critical steps during cutting propagation is the transplantation from the rooting medium to the nursery soil. The adventive roots are devoid of mycorrhizas and attacked by soil born pathogens. Inoculation of ectomycorrhizal fungi can improve root and shoot development of cuttings during the nursery phase [12]. To investigate the survival of the inoculated Laccaria bicolor S238N strain on Douglas fir cuttings during the nursery phase and after field transplantation, we have used morphological and genotyping methods. The pros and cos of these two methods of ectomycorrhizal assessment are discussed in this paper.

\section{MATERIALS AND METHODS}

\subsection{Fungal strains}

The American strain S238N of Laccaria bicolor (Maire) P.D. Orton was isolated by Trappe and Molina in 1976 from a basidioma under Tsuga mertensiana at Crater Lake National Park, Oregon, USA. This isolate was formerly accessioned and distributed as Laccaria laccata (Scop.: Fr.) Cooke. According to rRNA gene restriction patterns and culture morphology [2], it was reclassified as Laccaria bicolor. A sub-culture was transferred to the INRA fungal collection (Nancy, France) in March 1980 [8] and then sub-cultured every 2-3 months on solid modified Pachlewski's medium (7.3 mM $\mathrm{KH}_{2} \mathrm{PO}_{4}, 2.7 \mathrm{mM}$ di-ammonium tartrate, $7.3 \mathrm{mM} \mathrm{MgSO}_{4} 7 \mathrm{H}_{2} \mathrm{O}, 100 \mathrm{mM}$ glucose, $2.9 \mathrm{mM}$ thiamine- $\mathrm{HCl}$ and $1 \mathrm{~mL}$ of a trace element stock solution (Kanieltra Co.) in $2.0 \%$ agar, in Petri dishes at $25^{\circ} \mathrm{C}$. Other ectomycorrhizal strains were collected in French or European forests and compared to Laccaria bicolor S238N.

\subsection{Preparation of inoculum}

The Laccaria bicolor $\mathrm{S} 238 \mathrm{~N}$ isolate was produced in fermentor and entrapped in alginate beads, using techniques described by Le Tacon et al. [18] [10 g of alginate, $30 \mathrm{~g}$ of ground peat and $1 \mathrm{~g}$ of mycelium (dry weight) per litre of inoculum]. 


\subsection{Preparation of Douglas fir cuttings}

Douglas fir cuttings originated from the INRA Seed Orchard No. 24, established at Bout (Allier, France) and constituted with trees selected in USA for better growth and later bud break. The three-year-old outdoor mother trees were established in raised beds at the nursery of Nogent-sur-Vernisson (France), trimmed every year. Dates of cuttings selection were 17th and 18th of January and 13th and 24th of February 1992. The cuttings were cold-stored in plastic-bags at a temperature of about $2{ }^{\circ} \mathrm{C}$ during 3 to 5 weeks.

\subsubsection{Rooting conditions}

The peat-vermiculite substrate (1:1 vol.) was fumigated with methyl bromide 2 weeks before cuttings insertion. The cuttings were maintained in a greenhouse with a humidity control based on mist or/and fog system. Two months after insertion of the cuttings, a weekly fertilising regime was applied with a N-P-K 10-10-10 growth solution.

\subsection{Nursery experiment}

\subsubsection{Soil management and fungal inoculation}

The nursery experiment was set up in 1992 in the nursery of Peyrat-le-Château (Haute-Vienne, France). The soil was a brown podzolic soil developed on granite and chemically improved by fifteen years of intensive fertilisation. The experiment was a complete block design with 2-square-metre plots separated from each other by $50-\mathrm{cm}$ unplanted buffer zones. Three treatments with four replicates were applied: control, soil fumigation with methyl bromide, soil fumigation with methyl bromide and fungal inoculation.

The soil was fumigated with cold methyl bromide ( $75 \mathrm{~g} / \mathrm{m}^{2}$, soil covered with polyethylene film for 4 days) 3 weeks before the inoculation and cuttings planting. The L. bicolor $\mathrm{S} 238 \mathrm{~N}$ inoculum (one litre of inoculum per square meter) was incorporated to the soil just before outplanting.

\subsubsection{Cutting harvesting and mycorrhizal assessment}

After a two-year growing period in the nursery, the mycorrhizal status of five cuttings per plot was assessed. After lifting, the roots of each cutting were separated from soil, washed and cut into pieces $1 \mathrm{~cm}$ long. Pieces of roots were randomly picked and examined for ectomycorrhizal development under a dissecting microscope. All short roots up to 200 were counted in this subsample, recording separately different morphotypes (Laccaria, Thelephora, Rhizopogon and others). Morphological features used in morphotyping were as follows:

Laccaria-like type: single mycorrhizas often tortuous, 2-10 mm long, 1-2 mm wide, cottony textured, whitish to brown mantle and abundant emanating hyphae with abundant clamp connections.

Thelephora-like type: pinnately branched mycorrhizas, 2-4 mm long, smooth to rough, light to medium brown mantle, cystidia, relatively frequent emanating hyphae with clamp connections and white strands occasionally present.

Rhizopogon-like type: single to pinnately branched or tuberculate mycorrhizas, white to light brown, rough mantle, abundant emanating hyphae without clamp connections and abundant strands forming mats.

Cenococcum-like type: single mycorrhizas, rough and black, 1 to $3 \mathrm{~mm}$ long and black abundant emanating hyphae without clamp connections.

One hundred mycorrhizal tips per treatment were sampled according the percentage of the different morphotypes for further DNA analysis.

Cuttings shoot height was also measured before field transplantation.

\subsection{Field mycorrhizal trial}

The two-year-old Douglas fir cuttings were transplanted in March 1994 in a recently cultivated soil located in the East of France near Nancy (elevation 226 m, annual rainfall $800 \mathrm{~mm}$, mean annual temperature $8.4{ }^{\circ} \mathrm{C}$ ). The experiment was established as a fully randomised complete block design, consisting of four blocks. The three nursery treatments (control, soil fumigation with methyl bromide, soil fumigation with methyl bromide and fungal inoculation) were set up as plots of at least 45 trees, separated by a $5-\mathrm{m}$ non-planted buffer zone. Before planting, the ground was prepared by excavating individual holes.

\subsubsection{Plant measurements}

Each year after outplanting, height of all cuttings was measured. 


\subsubsection{Mycorrhizal assessment}

Three years after transplantion, two long roots were carefully excavated from 5 cuttings per plot. Ectomycorrhizal morphotypes and ribotypes were determined as previously described [16] for mycorrhizal assessment at the end of the nursery phase.

\subsection{DNA extraction and PCR amplification}

Total DNA was extracted from single ectomycorrhizal tip or from fungal pure cultures by a rapid method using proteinase K/CTAB and Phenol/chloroform according to Henrion et al. [15]. The proximal part of the nuclear rDNA intergenic spacer (IGS1) was amplified using the primers CNL12 and 5SA [15]. The total internal transcribed spacer $(\mathrm{ITS}=\mathrm{ITS} 1+\mathrm{ITS} 2+5,8 \mathrm{~S})$ was amplified using the primers ITS1F and ITS4B specific of the fungi [11]. The oligonucleotide primers were synthesised and supplied by Bioprobe Systems (Montreuil-sous-Bois, France). For PCR reactions, total DNA (0.1 to $10 \mathrm{ng}$ ), Taq DNA polymerase buffer [20 mM Tris ( $\mathrm{pH} 8.3$ at $25^{\circ} \mathrm{C}$ ), $1,5 \mathrm{mM} \mathrm{MgCl}_{2}, 50 \mathrm{mM}$ $\mathrm{KCl}$, $200 \mathrm{mM}$ dNTP, $0.02 \mathrm{mM}$ of each set of relevant primers and 1 unit of Taq DNA polymerase (Appligène, France) were mixed in a $200-\mu \mathrm{L}$ polypropylene tube. 20 to 30 PCR cycles ensued in GeneAmp PCR System 9600 (Perkin Elmer). The thermal cycling parameters were an initial denaturation at $94{ }^{\circ} \mathrm{C}$ for $3 \mathrm{~min}$, followed by 25 to 30 cycles of denaturation at $94{ }^{\circ} \mathrm{C}$ for $1 \mathrm{~min}$, annealing at $50{ }^{\circ} \mathrm{C}$ for $30 \mathrm{~s}$, and extension at $72^{\circ} \mathrm{C}$ for $2 \mathrm{~min}$, with a final extension at $72{ }^{\circ} \mathrm{C}$ for $10 \mathrm{~min}$. Controls with no DNA were done at each amplification in order to detect a possible contamination from reagents and reaction buffers.

\subsection{Restriction digest and electrophoresis}

One tenth of the amplified ITS and IGS was digested with the restriction enzyme HinfI or a mix of EcoRI and $R s a \mathrm{I}$ according to the manufacturer's instructions (New England Biolabs, Montigny-le-Bretonneux, France). Amplification and restriction products were analysed by $8.0 \%$ acrylamide gel electrophoresis (PAGE) [24]. ФX174-DNA, digested with HaeIII, was used as a size standard. Gels were stained using ethidium bromide and photographed under U.V. light.

\subsection{Statistical analysis}

The variance homogeneity of each parameter was confirmed by the Burr-Foster test [1] and all data were subjected to analysis of variance. The percentage of the different ectomycorrhizal morphotypes was statistically analysed with UNISTAT after square root arcsinus transformation of the data. The Duncan test was used for the means comparison.

\section{RESULTS}

\subsection{Ectomycorrhizal morphotypes}

Rhizopogon and Cenococcum morphotypes were easily identified, whereas the distinction between the Laccaria and Thelephora-like types was difficult and could lead to confusion. In addition, by morphological assessment it was impossible to distinguish Laccaria bicolor S238N mycorrhizas from mycorrhizas formed by naturally occurring Laccaria strains.

Only four ectomycorrhizal morphotypes (three in nursery conditions and four in plantations) were identified on Douglas fir cuttings. Each morphotype was expressed as per cent of total short roots and per cent of total mycorrhizas.

\subsection{Molecular typing of ectomycorrhizal fungi and mycorrhizas}

\subsubsection{Interspecific and intraspecific variabilities in the ITS and IGS region of ectomycorrhizal fungi}

The variability of the rDNA ITS between ectomycorrhizal species collected in the nursery of Peyrat-leChâteau or in different plantations was high (data not shown). The size of the amplified ITS ranged from 563 (e.g. Lactarius chrysorrheus) to $1224 \mathrm{bp}$ (Lactarius rufus). RFLP patterns exhibited from one to four fragments with RsaI and EcoRI and from three to seven with HinfI (table I). A comprehensive set of the obtained PCR/RFLP patterns will be available at the following URL:http.//mycor.nancy.fr/MolEcol.home. Using the endonucleases HinfI, RsaI and EcoRI, the majority of the analysed species were distinguished.

In contrast, intraspecific ITS variation of the investigated species was low, which is in accordance with previous studies of the ITS region of ectomycorrhizal fungi [9, 17]. Amongst species of Laccaria bicolor and L. laccata, the intraspecific variation in the ITS region was limited (table I).

Heteroduplex formation in the IGS of the rDNA (table II and figure 2) allowed the identification of Laccaria bicolor S238N in Douglas fir mycorrhizas $[16,25]$. 
Table I. Fragment size of the amplified rDNA ITS of different ectomycorrhizal ribotypes after HinfI digestion. The total size is the sum of the size of the RFLP fragments. The apparent size $(3547 \mathrm{~kb})$ of the amplified rDNA ITS of the Rhizopogon ribotype is due to the formation of an heteroduplex. The apparent size $(3547 \mathrm{~kb})$ of the amplified rDNA ITS of the Rhizopogon ribotype is due to the formation of an heteroduplex.

\begin{tabular}{lccccccc}
\hline Species & Total size of ITS (bp) & \multicolumn{5}{c}{ RFLP/ HinfI } \\
\hline Laccaria bicolor S238N & 620 & 315 & 191 & 113 & & \\
Indigenous Laccaria Peyrat & 620 & 315 & 191 & 113 & & \\
Type 1/2 & 580 & 263 & 164 & 150 & & & \\
Type 2/1 & 650 & 303 & 230 & 113 & & & \\
Type 1/3 & 670 & 326 & 152 & 110 & 79 & & \\
Rhizopogon & 3547 & 214 & 193 & 134 & 123 & 113 & 105 \\
& 575 & & & & & & \\
Thelephora & 650 & 229 & 162 & 132 & & & \\
\hline
\end{tabular}

Table II. Fragment size of the amplified rDNA IGS1 of Laccaria bicolor S238N and of two naturally occurring fungi of the nursery: Laccaria laccata and Thelephora terrestris, after HinfI digestion. The total size is the sum of the size of the RFLP fragments. The two bands of high molecular weight, which allows the characterization of Laccaria bicolor S238N, are due to the formation of an heteroduplex.

\begin{tabular}{lccccc}
\hline Species & Total size of IGS1 (bp) & \multicolumn{3}{c}{ RFLP/ HinfI } \\
\hline Laccaria bicolor S238N & 2400 & 629 & 424 & 164 & 139 \\
& 2200 & & & & \\
Indigenous Laccaria Peyrat & 800 & 300 & 185 & 145 & \\
Thelephora terrestris & 723 & 300 & 145 & 94 & 81 \\
\hline
\end{tabular}

Besides L. bicolor $\mathrm{S} 238 \mathrm{~N}$ identification by amplification products of the IGS1 region, seven different patterns of the ITS region, digested by HinfI, were detected for all the mycorrhizas in all the treatments, both in nursery and outplanting sites (figure 1 and table I). In nursery, the rate of fungal rDNA amplification in mycorrhizas was different between the treatments: $56 \%$ in the control and $74 \%$ in the treatments where the soil was previously fumigated (table III). In field conditions, the rate of amplification was better (between 75 and 83\%) and similar between the three treatments (table IV). We were unable to amplify the fungal ITS rDNA of the Rhizopogon morphotype from mycorrhizas coming from the plantation site, whereas the amplification of Rhizopogon mycorrhizas coming from the nursery was easy.

\subsection{Survival and effect of Laccaria bicolor $\mathbf{S 2 3 8 N}$ on Douglas fir cuttings growth in nursery conditions}

At the end of the nursery phase, $74 \%$ of the root tips of the control cuttings were mycorrhizal (table $V$ ).
Rhizopogon morphotypes were dominant and represented $76 \%$ of the mycorrhizas, $17 \%$ of the mycorrhizas belonging to unidentified morphotypes. Only some Thelephora and Laccaria morphotypes were recorded. Laccaria bicolor $\mathrm{S} 238 \mathrm{~N}$ was not detected by molecular typing (table III).

Soil fumigation greatly modified the mycorrhizal status of Douglas fir cuttings. The rate of colonization (58\%) was significantly decreased compared to the control. Rhizopogon mycorrhizas were reduced to $24 \%$ of the mycorrhizas. The majority of mycorrhizas were Laccaria-like morphotypes. Genotyping (table III) showed that these Laccaria-like mycorrhizas were composed of the introduced Laccaria bicolor S238N mycorrhizas $(17.7 \%)$, naturally occurring Laccaria mycorrhizas (12.9\%) and unknown species (type 1/2, $6.7 \%$; type $2 / 1,16.3 \%$; undetermined, $2.2 \%$ ).

In the treatment where the soil was fumigated and the cuttings inoculated with Laccaria bicolor S238N, $62 \%$ of the root tips were mycorrhizal. Rhizopogon colonisation 


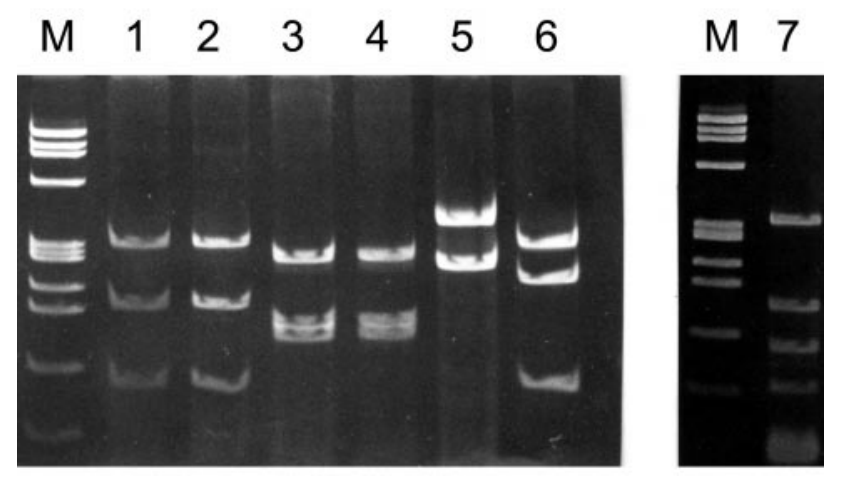

Figure 1. RFLP/HinfI of ITS products of Douglas fir ectomycorrhizas on acrylamide gel stained by ethidium bromide: M, molecular marker phage $\Phi X 174$ digested by HaeIII; 1, Laccaria bicolor; 2, indigenous Laccaria; 3 and 4, type 1/2; 5, type present only on some samples; 6 , type $2 / 1 ; 7$ type $1 / 3$. (a)

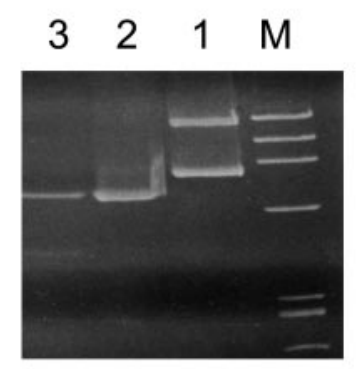

(b)

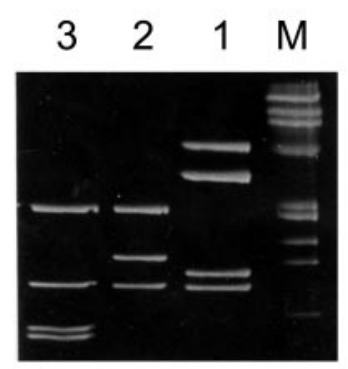

Figure 2. (a) IGS 1 products of Douglas fir ectomycorrhizas. M, molecular marker phage $\Phi$ X174 digested by HaeIII; 1, Laccaria bicolor $\mathrm{S} 238 \mathrm{~N}$; 2, indigenous Laccaria; 3, Thelephora terrestris. (b) RFLP/HinfI of IGS1 products of ectomycorrhizas from Douglas fir. M, molecular marker phage $\Phi X 174$ digested by HaeIII; 1, Laccaria bicolor S238N; 2, indigenous Laccaria; 3, Thelephora terrestris.

was reduced to $6 \%$ of the mycorrhizas. The dominant morphotype was the Laccaria-like type, mainly constituted by Laccaria bicolor S238N mycorrhizas (59.2\%) as shown by the IGS-type of the reference isolate $\mathrm{S} 238 \mathrm{~N}$.

Two years after inoculation, there were no significant differences in cuttings survival between the three treatments. On the contrary, height growth was affected by the treatments. Soil fumigation and inoculation with Laccaria bicolor $\mathrm{S} 238 \mathrm{~N}$ greatly enhanced Douglas fir cuttings growth (table VI).

\subsection{Survival and effect of Laccaria bicolor $\mathbf{S 2 3 8 N}$ on Douglas fir cuttings after field transplantation}

Three years after tranplantation, the mycorrhizal status of the control cuttings inherited from the nursery was completely modified. The Rhizopogon morphotype, which was dominant at the end of the nursery phase, had disappeared and had been replaced by Laccaria like mycorrhizas or undetermined morphotypes (table VII). Genotyping (table IV) showed that these Laccaria-like mycorrhizas or undetermined mycorrhizas were mainly formed by a new ribotype (ribotype 1/3) coming from the plantation site. Its ITS rDNA pattern was different from the several hundreds patterns recorded in the INRA MycoMol database or in other ITS databases $[15,20]$.

The main mycorrhizal morphotype of the cuttings produced in fumigated soil but not artificially inoculated belonged to an undetermined one (table VII). Genotyping showed that this undetermined morphotype was formed by a mix of Laccaria bicolor $\mathrm{S} 238 \mathrm{~N}$ mycorrhizas and mycorrhizas of ribotypes $1 / 2,2 / 1$ and $1 / 3$ (table $V I$ ). Some Rhizopogon mycorrhizas were still present in this treatment.

On the cuttings inoculated with Laccaria bicolor $\mathrm{S} 238 \mathrm{~N}$, the short roots colonised by the Rhizopogon morphotype was enhanced (6\% of the total mycorrhizas at the end of the nursery phase and $25.7 \%$ two years after transplantation). The dominant morphotype was a Laccaria one (table VII). Genotyping demonstrated that this Laccaria-like type was mainly formed by the introduced strain L. bicolor $\mathrm{S} 238 \mathrm{~N}$ (table IV). Expressed as per cent of amplified mycorrhizas, the IGS-type of the inoculant strain S238N had slightly decreased after field transplantation (59\% at the end of the nursery phase and $37.5 \%$ two years after outplanting). The ribotype $1 / 2$, which was weakly present in the nursery $(1.5 \%$ of the amplified mycorrhizas), considerably extended two years after field transplantation $(41.5 \%)$. On the contrary, the naturally occurring $1 / 3$ ribotype from the plantation site was unable to colonise the artificially inoculated cuttings.

Three years after transplantation, there were no significant differences in cuttings survival between the three treatments, but the height of the control cuttings and their annual shoot were significantly weaker than in the other two treatments (table VI). 
Table III. Percentage of ectomycorrhizal ribotypes (ITS and IGS1 spacers) on roots of Douglas fir cuttings at the end of the nursery phase (Peyrat-le-Château nursery). Nursery treatments: I control, II fumigated soil, III fumigated soil and inoculation with Laccaria bicolor S238N. Treatments with different letters are significantly different (Duncan test).

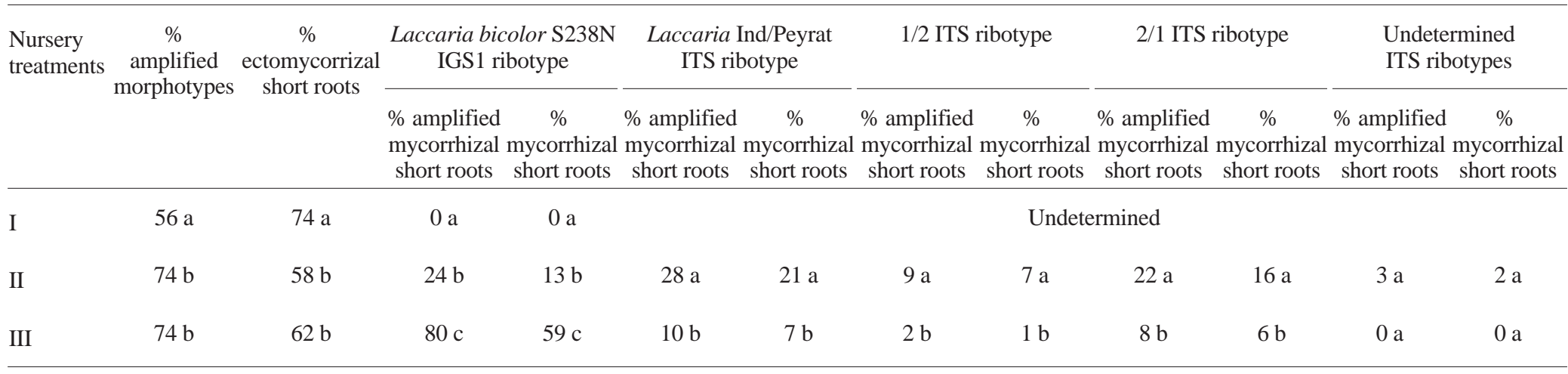

Table IV. Percentage of ectomycorrhizal ribotypes (ITS and IGS1 spacers) on roots of Douglas fir cuttings three years after transplantation on a recently cultivated soil. Nursery treatments: I control, II fumigated soil, III fumigated soil and inoculation with Laccaria bicolor S238N. Treatments with different letters are significantly different (Duncan test).

\begin{tabular}{|c|c|c|c|c|c|c|c|c|c|c|c|c|}
\hline \multirow[t]{2}{*}{$\begin{array}{l}\text { Nursery } \\
\text { treatments }\end{array}$} & \multirow{2}{*}{$\begin{array}{c}\% \\
\text { ectomycorrhizal } \\
\text { short roots }\end{array}$} & \multirow{2}{*}{$\begin{array}{c}\% \\
\text { amplified } \\
\text { ribotypes }\end{array}$} & \multicolumn{2}{|c|}{$\begin{array}{c}\text { Laccaria bicolor } \mathrm{S} 238 \mathrm{~N} \\
\text { IGS1 ribotype }\end{array}$} & \multicolumn{2}{|c|}{ 1/3 ITS ribotype } & \multicolumn{2}{|c|}{ 1/2 ITS ribotype } & \multicolumn{2}{|c|}{ 2/1 ITS ribotype } & \multicolumn{2}{|c|}{$\begin{array}{l}\text { Undetermined } \\
\text { ITS ribotypes }\end{array}$} \\
\hline & & & $\begin{array}{c}\% \\
\text { amplified } \\
\text { mycorrhizal } \\
\text { short roots }\end{array}$ & $\begin{array}{c}\% \\
\text { mycorrhizal } \\
\text { short roots }\end{array}$ & $\begin{array}{c}\% \\
\text { amplified } \\
\text { mycorrhizal } \\
\text { short roots }\end{array}$ & $\begin{array}{c}\% \\
\text { mycorrhizal } \\
\text { short roots }\end{array}$ & $\begin{array}{c}\% \\
\text { amplified } \\
\text { mycorrhizal } \\
\text { short roots }\end{array}$ & $\begin{array}{c}\% \\
\text { mycorrhizal } \\
\text { short roots }\end{array}$ & $\begin{array}{c}\% \\
\text { amplified } \\
\text { mycorrhizal } \\
\text { short roots }\end{array}$ & $\begin{array}{c}\% \\
\text { mycorrhizal } \\
\text { short roots }\end{array}$ & $\begin{array}{c}\% \\
\text { amplified } \\
\text { mycorrhizal } \\
\text { short roots }\end{array}$ & $\begin{array}{c}\% \\
\text { mycorrhizal } \\
\text { short roots }\end{array}$ \\
\hline I & $90 \mathrm{a}$ & $80 \mathrm{a}$ & $0 \mathrm{a}$ & $0 \mathrm{a}$ & $88 \mathrm{a}$ & $70 a$ & $0 \mathrm{a}$ & $0 \mathrm{a}$ & $0 \mathrm{a}$ & $0 \mathrm{a}$ & $12 \mathrm{a}$ & $9 \mathrm{a}$ \\
\hline II & $50 \mathrm{~b}$ & $75 \mathrm{~b}$ & $18 \mathrm{~b}$ & $13 \mathrm{~b}$ & $29 \mathrm{~b}$ & $22 b$ & $39 \mathrm{~b}$ & $29 \mathrm{~b}$ & $14 \mathrm{~b}$ & $10 \mathrm{~b}$ & $0 \mathrm{~b}$ & $0 \mathrm{~b}$ \\
\hline III & $90 \mathrm{a}$ & $83 a$ & $45 \mathrm{c}$ & $37 \mathrm{c}$ & $0 \mathrm{c}$ & $0 \mathrm{c}$ & $50 \mathrm{c}$ & $41 \mathrm{c}$ & $4 \mathrm{c}$ & $3 \mathrm{c}$ & $1 \mathrm{~b}$ & $1 \mathrm{~b}$ \\
\hline
\end{tabular}


Table V. Percentage of ectomycorrhizal morphotypes on roots of Douglas fir cuttings at the end of the nursery phase (Peyrat-le-Château nursery). Nursery treatments: I control, II fumigated soil, III fumigated soil and inoculation with Laccaria bicolor S238N. Treatments with different letters are significantly different (Duncan test).

\begin{tabular}{|c|c|c|c|c|c|c|c|c|c|}
\hline \multirow{2}{*}{$\begin{array}{l}\text { Nursery } \\
\text { treatments }\end{array}$} & \multirow{2}{*}{$\begin{array}{c}\% \text { ectomycorrhizal } \\
\text { short roots }\end{array}$} & \multicolumn{2}{|c|}{ Laccaria morphotype } & \multicolumn{2}{|c|}{ Thelephora morphotype } & \multicolumn{2}{|c|}{ Rhizopogon morphotype } & \multicolumn{2}{|c|}{ Undetermined morphotypes } \\
\hline & & $\begin{array}{l}\% \text { mycorrhizal } \\
\text { short roots }\end{array}$ & $\begin{array}{l}\% \text { total short } \\
\text { roots }\end{array}$ & $\begin{array}{l}\% \text { mycorrhizal } \\
\text { short roots }\end{array}$ & $\begin{array}{l}\% \text { total short } \\
\text { roots }\end{array}$ & $\begin{array}{l}\% \text { mycorrhizal } \\
\text { short roots }\end{array}$ & $\begin{array}{l}\% \text { total short } \\
\text { roots }\end{array}$ & $\begin{array}{l}\% \text { mycorrhizal } \\
\text { short roots }\end{array}$ & $\begin{array}{l}\% \text { total short } \\
\text { roots }\end{array}$ \\
\hline I & $74 \mathrm{a}$ & $0.3 \mathrm{a}$ & $0.2 \mathrm{a}$ & $7 \mathrm{a}$ & $5 \mathrm{a}$ & $76 a$ & $56 \mathrm{a}$ & $17 \mathrm{a}$ & $13 \mathrm{a}$ \\
\hline II & $58 \mathrm{~b}$ & $67 \mathrm{~b}$ & $39 \mathrm{~b}$ & $7 \mathrm{a}$ & $4 \mathrm{a}$ & $24 \mathrm{~b}$ & $14 \mathrm{~b}$ & $0 \mathrm{~b}$ & $0 \mathrm{~b}$ \\
\hline III & $62 \mathrm{~b}$ & $88 \mathrm{~b}$ & $55 \mathrm{~b}$ & $8 \mathrm{a}$ & $5 \mathrm{a}$ & $6 b$ & $4 \mathrm{~b}$ & $1 \mathrm{~b}$ & $1 \mathrm{~b}$ \\
\hline
\end{tabular}

Table VI. Growth (tree height and shoot of the year) of Douglas fir cuttings after the nursery phase and three years after field transplantation in a recently cultivated soil. Nursery treatments: I control, II fumigated soil, III fumigated soil and inoculation with Laccaria bicolor S238N. Treatments with different letters are significantly different (Duncan test).

\begin{tabular}{|c|c|c|c|c|c|c|c|c|}
\hline $\begin{array}{l}\text { Nursery } \\
\text { treatments }\end{array}$ & $\begin{array}{l}\text { Height at the } \\
\text { end of the } \\
\text { nursery phase } \\
(\mathrm{cm})\end{array}$ & $\begin{array}{l}\text { Height one year } \\
\text { after field } \\
\text { transplantation } \\
(\mathrm{cm})\end{array}$ & $\begin{array}{l}\text { Shoot of the year } \\
\text { one year after field } \\
\text { transplantation } \\
(\mathrm{cm})\end{array}$ & $\begin{array}{l}\text { Height two years } \\
\text { after field } \\
\text { transplantation } \\
(\mathrm{cm})\end{array}$ & $\begin{array}{l}\text { Shoot of the year } \\
\text { two years after field } \\
\text { transplantation } \\
(\mathrm{cm})\end{array}$ & $\begin{array}{l}\text { Height three years } \\
\text { after field } \\
\text { transplantation } \\
(\mathrm{cm})\end{array}$ & $\begin{array}{l}\text { Shoot of the year } \\
\text { three years after } \\
\text { field transplantation } \\
(\mathrm{cm})\end{array}$ & $\begin{array}{c}\text { Rate of survival } \\
\text { three years after } \\
\text { transplantation } \\
(\%)\end{array}$ \\
\hline I & $26.1 \mathrm{a}$ & $39.8 \mathrm{a}$ & $13.7 \mathrm{a}$ & $67.5 \mathrm{a}$ & $27.7 \mathrm{a}$ & $104.6 \mathrm{a}$ & $37.1 \mathrm{a}$ & $99.4 \mathrm{a}$ \\
\hline II & $30.6 \mathrm{~b}$ & $49.4 \mathrm{~b}$ & $18.8 \mathrm{~b}$ & $78.3 \mathrm{~b}$ & $28.9 \mathrm{a}$ & $120.2 \mathrm{~b}$ & $41.9 \mathrm{~b}$ & $100.0 \mathrm{a}$ \\
\hline
\end{tabular}


Table VII. Percentage of ectomycorrhizal morphotypes on roots of Douglas fir cuttings three years after transplantation on a recently cultivated soil. Nursery treatments: I control, II fumigated soil, III fumigated soil and inoculation with Laccaria bicolor S238N. Treatments with different letters are significantly different (Duncan test).

\begin{tabular}{|c|c|c|c|c|c|c|c|c|c|c|c|}
\hline \multirow[t]{2}{*}{$\begin{array}{l}\text { Nursery } \\
\text { treatments }\end{array}$} & \multirow{2}{*}{$\begin{array}{c}\% \\
\text { ectomycorrhizal } \\
\text { short roots }\end{array}$} & \multicolumn{2}{|c|}{ Laccaria morphotype } & \multicolumn{2}{|c|}{ Thelephora morphotype } & \multicolumn{2}{|c|}{ Rhizopogon morphotype } & \multicolumn{2}{|c|}{$\begin{array}{l}\text { Cenococcum geophilum } \\
\text { morphotype }\end{array}$} & \multicolumn{2}{|c|}{$\begin{array}{l}\text { Undetermined } \\
\text { morphotypes }\end{array}$} \\
\hline & & $\begin{array}{c}\% \\
\text { mycorrhizal } \\
\text { short roots }\end{array}$ & $\begin{array}{l}\% \\
\text { total short } \\
\text { roots }\end{array}$ & $\begin{array}{c}\% \\
\text { mycorrhizal } \\
\text { short roots }\end{array}$ & $\begin{array}{l}\% \\
\text { total short } \\
\text { roots }\end{array}$ & $\begin{array}{c}\% \\
\text { mycorrhizal } \\
\text { short roots }\end{array}$ & $\begin{array}{l}\% \\
\text { total short } \\
\text { roots }\end{array}$ & $\begin{array}{c}\% \\
\text { mycorrhizal } \\
\text { short roots }\end{array}$ & $\begin{array}{l}\% \\
\text { total short } \\
\text { roots }\end{array}$ & $\begin{array}{c}\% \\
\text { mycorrhizal } \\
\text { short roots }\end{array}$ & $\begin{array}{c}\% \\
\text { total } \\
\text { short roots }\end{array}$ \\
\hline I & $90 \mathrm{a}$ & $47 \mathrm{a}$ & $42 \mathrm{a}$ & $3 \mathrm{a}$ & $3 \mathrm{a}$ & $0 \mathrm{a}$ & $0 \mathrm{a}$ & $1 \mathrm{a}$ & $1 \mathrm{a}$ & $49 \mathrm{a}$ & $44 \mathrm{a}$ \\
\hline III & $90 \mathrm{a}$ & 45. a & $41 \mathrm{a}$ & $0 \mathrm{a}$ & $0 \mathrm{a}$ & $26 \mathrm{~b}$ & $23 \mathrm{~b}$ & $0 \mathrm{a}$ & $0 \mathrm{a}$ & $29 c$ & $26 \mathrm{~b}$ \\
\hline
\end{tabular}




\section{DISCUSSION}

In nursery conditions, two years after inoculation, morphotypes assessment of Laccaria mycorrhizas gave similar result to ribotypes analysis in the different treatments. As we have previously shown [16], morphotyping did not allow the distinction among Laccaria bicolor S238N mycorrhizas and mycorrhizas formed by naturally occurring Laccaria strains. Thelephora and Rhizopogon morphotypes were detected in all the treatments. Apart the possibility of distinguishing Laccaria bicolor $\mathrm{S} 238 \mathrm{~N}$ mycorrhizas from other Laccaria mycorrhizas, molecular analysis allowed the distinction of two new ribotypes which could not be related to known ectomycorrhizal fungi $(1 / 2$ and $2 / 1$ ITS ribotypes).

By combining morphotypes and ribotypes analysis, it was possible to relatively well characterise the mycorrhizal status of Douglas fir cuttings at the end of the nursery phase in the three treatments. The control cuttings were mainly colonised by Rhizopogon. Soil fumigation considerably reduced the occurrence of Rhizopogon. In the inoculated treatments, Laccaria bicolor $\mathrm{S} 238 \mathrm{~N}$ formed $80 \%$ of the short roots. The rest of the mycorrhizas were formed by naturally occurring Laccaria strains (7.4\%), Rhizopogon sp. (6\%), unknown fungi (1/2 and 2/1 ITS ribotypes) and Thelephora terrestris. The presence of Thelephora terrestris was attested by sporophores. In the treatment 2 (soil fumigation without mycorrhizal inoculation), Laccaria bicolor S238N surprisingly formed $24 \%$ of the mycorrhizal roots. This could be due an accidental contamination (animals or tools used for weeding) or to the spread of the inoculated strain from the inoculated plots to the noninoculated ones. Laccaria bicolor S238N abundantly fructifies at the autumn following the inoculation. Spores could have contaminated fumigated plots and mycelium issued from these spores could have formed mycorrhizas during the second year in the nursery.

In field conditions, three years after outplanting, in the treatment where the cuttings had been previously inoculated, morphotypes assessment of Laccaria mycorrhizas gave similar results to molecular analysis. $45 \%$ of the mycorrhizal short roots belonged to the Laccaria morphotype; molecular analysis confirmed that these Laccaria-like mycorrhizas were mainly formed by Laccaria bicolor S238N. In this treatment, $25 \%$ of the mycorrhizal short roots were Rhizopogon morphotypes. We were unable to amplify these Rhizopogon mycorrhizas coming from the outplanting site, although it was possible to amplify those sampled in the nursery. It is difficult to find an explanation for these difficulties of amplification: a change in the tannin composition of the host tissues due to ageing could be involved. The other mycorrhizas were also formed by a fungus coming from the nursery site ( $40 \%$ of the $1 / 2$ ITS ribotype).

In the treatment 2, where Laccaria bicolor $\mathrm{S} 238 \mathrm{~N}$ was accidentally introduced, this strain colonised $13 \%$ of the mycorrhizal short roots. Rhizopogon mycorrhizas were scarce, whereas the two ITS ribotypes coming from the nursery represented $40 \%$ of the mycorrhizal roots. A new ribotype (1/3 ITS), probably coming from the outplanting site, formed $20 \%$ of the mycorrhizas. In the control, almost all the mycorrhizas were formed by this new ribotype (1/3 ITS), naturally occurring in the planting site.

As in nursery conditions, by combining morphotypes and ribotypes assessment, it was possible, in the three treatments, to relatively well characterise the mycorrhizal status of Douglas fir cuttings two years after outplanting and four years after mycorrhizal inoculation. Three years after outplanting, five morphotypes and five ribotypes were found. Much more morphotypes were described on Douglas fir seedlings grown for 6-16 months in natural mixed forests of Pseudotsuga menziesii and Betula papyrifera in British Columbia [26]. The weak number of mycorrhizal types found in our experiment could be explain by the fact that the cuttings were transplanted in a recently cultivated soil and in an area where Douglas fir is an exotic species.

The comparison of the mycorrhizal status of Douglas fir cuttings at the end of the nursery phase and three years after outplanting shown several behaviours among the ectomycorrhizal fungi occurring in the nursery (figure 3). The Rhizopogon type disappeared after outplanting, while two other fungi (Laccaria bicolor S238N, 1/2 ITS ribotype) survived and competed with the naturally occurring fungi. This behaviour also was depending on the treatments. Nevertheless, in this planting site, the natural competitors were scarce. Cenococcum geophilum was almost completely absent. Two years after outplanting in natural forest sites in the Vosges area (East of France), Douglas fir seedlings formed abundant Cenococcum-like mycorrhizas. [29]. It seems that Cenococcum geophilum, which is a major competitor of Laccaria species in natural forest sites, is not able to rapidly recolonise previously cultivated soils. This could be due to the fact that Cenococcum geophilum does not produce sexual spores. Only one indigenous type (1/3 ITS ribotype) seemed occurring in this 

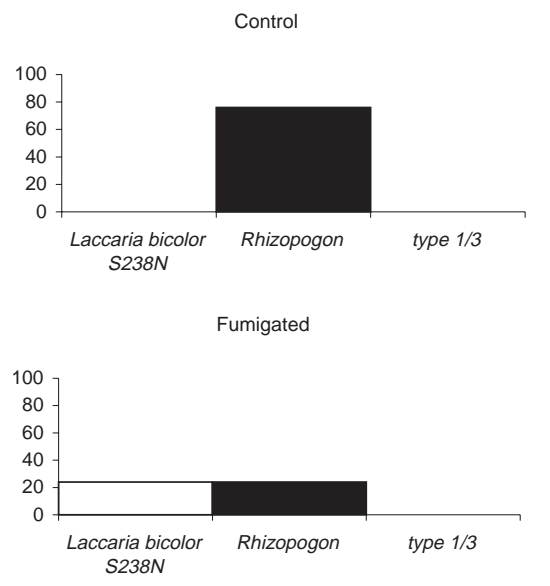

Inoculated

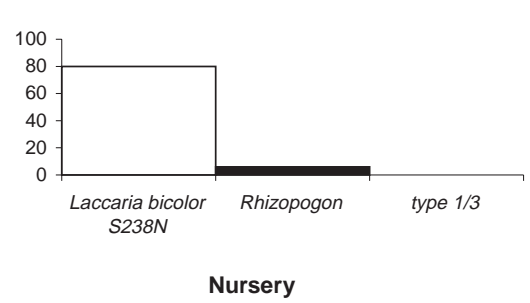

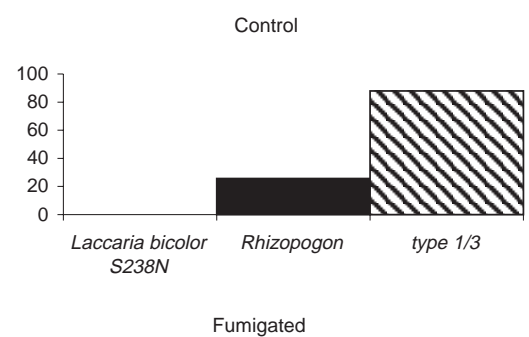

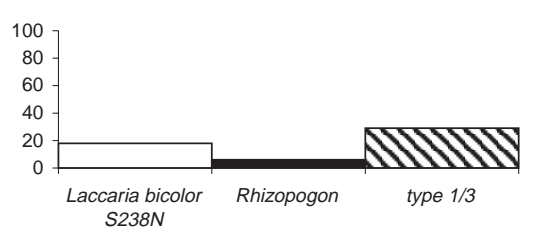

Inoculated

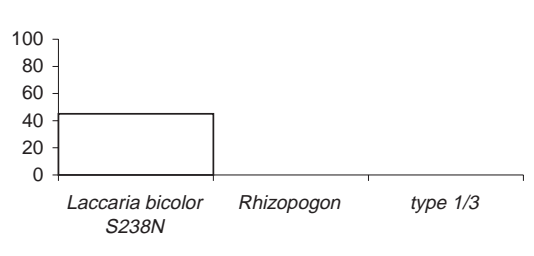

Three years after field plantation
Figure 3. Effect of nursery treatments and field transplantation on the percentage of colonisation of Douglas fir roots by three ectomycorrhizal types: Laccaria bicolor S238N, Rhizopogon sp. and ribotype $1 / 3$. outplanting site. To our knowledge, this is one of the first time that genotyping of mycorrhizas is used to track, several years after field transplantation, a specific fungal genotype.

Acknowlegments: We wish to thank Bernard Puton, owner of the Damelevières plantation, and an anonymous referee for helpful corrections. This work was supported by an EU Contract (AIR 3-CT 93-1742).

\section{REFERENCES}

[1] Anderson V.L., McLean R.A., Design of Experiments, Marcel Dekker, New York, 1974.

[2] Armstrong J.L., Fowles N.L., Rygiewicz P.T., Restriction fragment length polymorphisms distinguish ectomycorrhizal fungi, Plant Soil 116 (1989) 1-7.

[3] Bledsoe C.S., Tennyson K., Lopushinsky W., Survival and growth of outplanted Douglas-fir seedlings inoculated with mycorrhizal fungi, Can. J. Forest Res. 12 (1982) 720-723.
[4] Bruns T., Gardes M., Molecular tools for the identification of ectomycorrhizal fungi - taxon-specific oligonucleotide probes for suilloid fungi, Mol. Ecol. 2 (1993) 233-242.

[5] Bruns T.D., Szaro T.M., Gardes M., Cullings K.W., Pan J.J., Taylor D.L., Horton T.R., Kretzer A., Garbelotto M., Li Y.A., sequence database for the identification of ectomycorrhizal basidiomycetes by phylogenetic analysis. Mol. Ecol. 7 (1998) 257-272.

[6] Buscot F., Wipf D., Di Battista C., Munch J.C., Botton B., Martin F., DNA polymorphism in morels: PCR/RFLP analysis of the ribosomal DNA spacers and microsatellite-primed PCR, Mycol. Res. 100 (1996) 63-71.

[7] Danielson, R.M., Visser S., Host response to inoculation and behaviour of introduced and indigenous ectomycorrhizal fungi of jack pine grown on oil-sands tailings, Can. J. For. Res. 19 (1989) 1412-1421.

[8] Di Battista C., Selosse M.-A., Bouchard D., Stenström E., Le Tacon F., Variations in symbiotic efficiency, phenotypic characters and ploidy level among different isolates of the ectomycorrhizal basidiomycete Laccaria bicolor strain S238, Mycol. Res. 100 (1996) 1315-1324.

[9] Gardes M., White T.J., Fortin J.A., Bruns T.D., Taylor J.W., Identification of indigenous and introduced symbiotic fungi in ectomycorrhizæ by amplification of nuclear and mitochondrial ribosomal DNA, Can. J. Bot. 69 (1991) 180-190. 
[10] Gardes M., Mueller G.M., Fortin J.A., Kropp B.R., Mitochondrial DNA polymorphisms in Laccaria bicolor, L. laccata, L. proxima and L. amethystina, Mycol. Res. 95 (1991) 206-216.

[11] Gardes M., Bruns T.D., ITS primers with enhanced specificity for basidiomycetes: application to the identification of mycorrhizas and rusts, Mol. Ecol. 2 (1993) 113-118.

[12] Généré B., Le Tacon F., Amirault J.-M., Bouchard D., La mycorhization contrôlée des boutures d'Epicéa commun en pépinière, Rev. For. Fr. XLVI (1994) 49-58.

[13] Grove T.S., Le Tacon F., Mycorrhiza in plantation forestry, Adv. Plant Pathol., 23 (1993) 191-227.

[14] Gryta H., Debaud J.C., Marmeisse R., Population dynamics of the symbiotic mushroom Hebeloma cylindrosporum: mycelial persistence and inbreeding, Heredity 84 (2000) 294-302.

[15] Henrion B., Le Tacon F., Martin F., Rapid identification of genetic variation of ectomycorrhizal fungi by amplification of ribosomal RNA genes, New Phytol. 122 (1992) 289-298.

[16] Henrion B., Di Battista C., Bouchard D., Vairelles D., Thompson B.D., Le Tacon F., Martin F., Monitoring the persistence of Laccaria bicolor as an ectomycorrhizal symbiont of nursery-grown Douglas fir by PCR of the rDNA intergenic spacer, Molecul. Ecol. 3 (1994) 571-580.

[17] Karen O., Högberg N., Dahlberg A., Jonsson L., Nylund J.E., Inter- and intraspecific variation in the ITS region of rDNA of ectomycorrhizal fungi in Fennoscandia as detected by endonuclease analysis, New Phytol. 136 (1997) 313-325.

[18] Le Tacon F., Jung G., Mugnier J., Michelot P., Mauperin C., Efficiency in a forest nursery of an ectomycorhizal fungus inoculum produced in fermentor and entrapped in polymeric gels, Can. J. Bot. 63 (1985) 1664-1668.

[19] Le Tacon F., Alvarez I.F., Bouchard D., Henrion B., Jackson R.M., Luff S., Parlade J.I., Pera J., Stenström E., Villeneuve N., Walker C., Variations in field response of forest trees to nursery ectomycorrhizal inoculation in Europe, Mycorr- hizas Ecosyst. (1992) 119-134, Read et al. (Eds), C. A. B. International, Wallingford, Oxon OX10 8DE, UK.

[20] McAfee B.J., Fortin J.A., Competitive interactions of ectomycorrhizal mycobionts under field conditions, Can. J. Bot. 64 (1986) 848-852.

[21] Marx D.H., The role of mycorrhizae in forest production, in: TAPPI Conf. Ann. Meeting, Atlanta, 1977, pp. 151-161.

[22] Mikola P., Mycorrhizal symbiosis in forestry practice, in: Marks G.C., Kozlowsky T.T. (Eds.), Ectomycorrhizae, their Ecology and Physiology, Academic Press, New York, London, 1973, pp. 348-411.

[23] Richtie G.A., Tanaka Y., Meade R., Duke S.D., Field survival and early height growth of Douglas-fir rooted cuttings: relationship to stem diameter and root system quality, For. Ecol. Manag. 60 (1993) 237-256.

[24] Sambrook J., Fritsch E.F., Maniatis T., Molecular cloning: a laboratory manual, 2nd edn., Cold Spring Harbor Laboratory, Cold Spring Harbor, New York, 1989.

[25] Selosse M.-A., Costa G., Di Battista C., Le Tacon F., Martin F., Segregation and recombination of ribosomal haplotypes in the ectomycorrhizal basidiomycete Laccaria bicolor monitored by PCR and heteroduplex analysis, Curr. Genet. 30 (1996) 332-337.

[26] Simard S.W., Perry D.A., Smith J.E., Molina R., Effects of soil trenching on occurrence of ectomycorrhizas on Pseudotsuga menziesii seedlings grown in mature forest of Betula papyrifera and Pseudotsuga menziesii, New Phytol. 13 (1997) 327-340.

[27] Smith S.E., Read D.J., Mycorrhizal Symbiosis, 2nd edn., Academic Press, New York, 1997.

[28] Trappe J.M., Selection of fungi for ectomycorrhizal inoculation in nurseries, Annu. Rev. Phytopathol., 15 (1977) 203-222.

[29] Villeneuve N., Le Tacon F., Bouchard D., Survival of inoculated Laccaria bicolor in competition with native ectomycorrhizal fungi and effects on the growth of outplanted Douglasfir seedlings, Plant Soil 135 (1991) 9-170 